\title{
Fantasy in Modern Egyptian Drama
}

\author{
Mohamed Kamel Abdel-Daem \\ Lecturer in English, Shaqra University
}

\begin{abstract}
This paper is an attempt to spotlight the Arabic dramatic works in modern Egypt ( produced during the second half of the twentieth century and a little after), that are based on fantasy aspects. These plays are usually mingled with elements of science fiction, mirabilia, fairytales, travel journeys, animal stories, utopian dreams, dystopian nightmares. A few Egyptian playwrights have experimented in both science and dark fantasy mixed with folkloric and mythic components. This study highlights these fantasy plays, featuring: Tawfiq alHakim's Ahl el-Kahf ( The People of the Cave,1933), Shhrazad (Scheherazade,1934), Al-Mukhrij ( The Film Director), Bayt al-Naml ( The House of Ants ), Nahr al-Junun ( The River of Madness, 1935), Rehla ela al-Ghad ( Voyage to Tomorrow), Not a Thing out of Place (1966), Awdat el-Shabab ( The Return of Consciousness,1974), Sha'er ala el-Qamar ( A Poet on the Moon), Taqreer Qamary ( A Lunar Report), ElSultan El-Ha'er ( The Sultan's Dilemma,), Izis(Isis,1955), Al-Ta'am li-kul fam ( Food for Every Mouth,1963); Saad Makkawi's al-Maiet wal-Haii ( The Living Dead,1973), Lutfi Al-Khuli's al-Aranib (The Rabbits,1964), No'man Ashur's Lu'bat al-Zamen (Time Game,1980); Farouk Khorshid's Habazlem Bazaza ( The Wines of Babylon,1967); Ali Salim's Il-Nas illi fill-Sama'l-Tamina ( The People in the Eighth Heaven, 1963), Yusuf Idris's al-Jins al-Thalith (The Third Sex,1971), and other marvelous plays.
\end{abstract}

Key Words : fantasy, science fiction, myth, folklore, Egypt modern drama, utopia, dystopia

\section{Introduction}

Presenting a number of definitions is possibly a necessary introductory procedure to this study that will direct intellectual laser towards the Arabic fantasy plays in modern Egypt. Literary works of the fantastic often make their setting in unreal, imaginary places, such as a lunar, or an underground demons' realm, or in imagined times when blood sucking ghosts and witches prevail. The fantastic writers often tell about human or nonhuman characters, half-human, legendary creatures. Fantasy is defined as:

a general term for any kind of fictional work that is not primarily devoted to realistic representation of the known world. The category includes several literary genres ( e.g. dream vision, fable, fairy tale, romance, science fiction) describing imagined worlds in which magical powers and other impossibilities are accepted. Recent theories of fantasy have attempted to distinguish more precisely between the self-contained magical realms of the marvelous, the psychologically explicable delusions of the uncanny, and the inexplicable meeting of both in the fantastic (Baldick2008:126-7).

The $O E D$ tells us that the term fantastic refers to things that lie " only in imagination; proceeding merely from imagination, fabulous, imaginary, unreal" (721). Modern Egyptian playwrights often hint at real topics through taking inspiration from unseen past or future worlds. Fantasy often overlaps with the marvelous which is " a category of fiction in which supernatural, magical or other wondrous impossibilities are accepted as normal within an imagined world clearly separated from our own reality. The category includes fairy tales, many romances, and most science fiction, along with various other kinds of fantasy" ( Baldick 2008:196).

The reader of the fantastic literature is often tempted to omit the line between reality and fancy, and become confused by his attempt to naturally or supernaturally interpret the events in a novel or a play. This confusion is also shared by one or more characters, making one of the thought threads in the text . The reader then gets out of the fantastic by expressing his final opinion on the work, whether it is an allegory or a symbol; the character's perplexity may last. The work belongs to the uncanny if the reader's interpretation of its unusual events depends on reality rules, while the work belongs to the marvelous if the reader understands its puzzles on the basis of supernatural formulae. .

The fantastic therefore leads a life full of dangers, and may evaporate at any moment. It seems to be located on the frontier of two genres, the marvelous and the uncanny, rather than to be an autonomous genre. One of the great periods of supernatural literature, that of the Gothic novel, seems to confirm this observation. Indeed, we generally distinguish, within the literary Gothic, two tendencies: that of the supernatural explained (the "uncanny"),... Here we find not the fantastic in the strict sense, only genres adjacent to it. More precisely, the effect of the fantastic .... Once we have finished reading, we understand--in both cases--that what we call the fantastic has not existed ...the transformation from mind to matter has become possible....[In fantastic literature] a character will be readily multiplied.... The multiplication of personality, taken literally, is an immediate 
consequence of the possible transition between matter and mind: we are several persons mentally, we become so physically (Todorv,1975) .

Writers of the fantastic also remove the borderlines between the human mind and the tangible universe. The human mind often interacts with other human or non-human surroundings. The readers or the audience of the fantastic usually have the sense perception without seeing or hearing or comprehending the mediums that enact such perceptions. Romance is " a fictional story ... that relates improbable adventures of idealized characters in some remote or enchanted setting ... The term now embraces many forms of fiction from the Gothic ... and the ... escapist love story ... to the 'scientific romance' ... medieval romance is distinguished from epic its concentration on courtly love rather than warlike heroism" ( Baldick 2008:291).

Science fiction "deals with the effects of change on people in the real world as it can be projected into the past, the future, or to distant places. It often concerns itself with scientific or technological change, and it usually involves matters whose importance is greater than the individual or the community; often civilization or the race itself is in danger" (Gunn2002:16). Science fiction human characters often have the ability to achieve their development through their knowledge of reality. Other literary genres focus on the present communal interrelation as "the only important ... aspect of existence is the way in which people relate to each other" (Gunn2002: 20). Apart from American science fiction, literatures lack the quality of being pragmatic and problem-solving. Being determined by cultural and literary conventions, such literatures share many features with all sorts of the fantastic. Like modern Egyptian plays, these works display social dilemmas that are psychologically complex inasmuch as they show how reality defies fate.

Science fiction - a form of fiction that deals principally with the impact of actual or imagined science upon society or individuals - is a modern genre. Though writers in antiquity sometimes dealt with themes common to modern science fiction, their stories made no attempt at scientific and technological plausibility, the feature that distinguishes science fiction from earlier speculative writings and other contemporary speculative genres such as fantasy and horror. .. The customary "theatrics" of science fiction include prophetic warnings, utopian aspirations, elaborate scenarios for entirely imaginary worlds, titanic disasters, strange voyages, and political agitation of many extremist flavours, presented in the form of sermons, meditations, satires, allegories, and parodies - exhibiting every conceivable attitude toward the process of techno-social change, from cynical despair to cosmic bliss... (Encyclopedia Britannica).

Postmodern science fiction has rapidly developed into a very affecting subculture; it includes topics such as nuclear power and space travel. Mixed with utopian, dystopian aspects, science fiction depicts techno-social miracles that shake the readers' cultural prestige. Weird literature presents horrible, apparition tales; it contains a synthesis of myth, science fiction and the supernatural. Horror writing often scares the readers or audience by creating terror and fright by means of natural or supernatural elements. Escapist literature grants the reader inner freedom from surrounding reality by indulging in unusual and made-up circumstances or actions.

Men of art, who create a utopia, often present an ideal, unattainable society. They often try to look for earthly communal perfection, with a view to the after-death, innocent being. Platonic utopia displayed a selfruling town based on justice and freedom. Medieval works presented socio-political criticism by idealizing past qualities of chivalry and equality. Then the genre often began to refer to living in an imaginary realm with no evils(Abrams,2003). Dystopia, on the other hand, is " applied to any alarmingly unpleasant imaginary world, usually of projected future, ... to fictional works depicting such worlds ... a significant form of science fiction and satire" ( Baldick2008:100). An ecotopia is an ecological utopia that advocates environmentalism. Satiric art directs ridiculous attack against persons, socio-political conduct or forms.

The medieval-originated genre of the gothic often depicts nightmarish horror, mysterious and isolated settings. Gothic writers create uncanny realms that exist in the real world, though not easily accepted by the rational, civilized men. Gothic characters may be subject to pejorative feelings: scare, vengeance, spleen, etc. The works contain supernatural incidents: vanishing creatures, apparitions, half-dead or half-alive characters, thus:

Gothic fiction is a literature of nightmare. Among its conventions are found dream landscapes and figures of the subconscious imagination. Its fictional world gives form to amorphous fears and impulses common to all mankind, using an amalgam of materials, some torn from the author's own subconscious mind and some stuff of myth, folklore, fairy tale, and romance. It conjures up beings - mad monks, vampires, and demons - and settings - forbidding cliffs and glowering buildings, stormy seas and the dizzying abyss - that have literary significance and the properties of dream symbolism as well. Gothic fiction gives shape to concepts of the place of evil in the human mind. [...]Gothic fiction has been called escape literature, intended to inspire terror for terror's sake. ( MacAndrew1979: 3ff)

The uncanny, to Freud, " undoubtedly belongs to all that is terrible - to all that arouses dread and creeping horror" (Freud2003:368). A writer usually obliterates the barrier between fanciful and visible world to make the uncanny feeling be effective. This effect " can only come from the circumstance of the 'double' being 
a creation dating back to a very early mental stage, long since left behind, and one, no doubt, in which it" seemed to be much less hostile (Freud2003:389). Literature of the uncanny,

as it is depicted ... in stories and imaginative productions, ... is a much more fertile province than the uncanny in real life, for it contains the whole of the latter and something more besides... The contrast between what has been repressed and what has been surmounted cannot be transposed on to the uncanny in fiction without profound modification...The somewhat paradoxical result is that in the first place a great deal that is not uncanny in fiction would be so if it happened in real life... The imaginative writer has this license among many others, that he can select his world of representation so that it either coincides with the realities we are familiar with or departs from them in what particulars he pleases. We accept his ruling in every case. In fairy tales, for instance, the world of reality is left behind from the very start,... can exert no uncanny influence here; .... as soon as the writer pretends to move in the world of common reality... everything that would have an uncanny effect in reality has it in his story. But in this case he can even increase his effect and multiply it far beyond what could happen in reality, by bringing about events which never or very rarely happen in fact (Freud1953:219-52).

In doing this, the writer resorts to using superstitious elements in order that he can make the reader accept the alternative, fake reality he forms through the uncanny genre. Uncanny drama often creates a feeling of discomfort both with being exotic and normal. Farce is " a kind of comedy that inspires hilarity mixed with panic and cruelty in its audience through an increasingly rapid and improbable series of ludicrous confusions, physical disasters, and sexual innuendos among its stock characters" ( Baldick 2008: 126). In magic realistic works, unusual or charm aspects play a normal role in a down-to-earth, lifelike setting (Faris:5).

Supernatural literature tackles the contrary phenomena that occur as a result of explaining unbelievable natural events using rationalist criterion. The genre contains aspects such as: abnormalities, terror, illusion, vampires, demon tales, and insane personalities. It is based on

a belief in an otherworldly realm or reality that, in one way or another, is commonly associated with all forms of religion. Evidence of neither the idea of nature nor the experience of a purely natural realm is found among primitive people, who inhabit a wonder world charged with the sacred power (or mania), spirits, and deities. Primitive man associates whatever is experienced as uncanny or powerful with the presence of a sacred or numinous power; yet he constantly lives in a profane realm that is made comprehensible by a paradigmatic, mythical sacred realm. In the higher religions a gulf usually is created between the sacred and the profane, or the here and the beyond, and it is only with the appearance of this gulf that a distinction becomes drawn between the natural and the supernatural (Encyclopedia Britannica)

A fable is " a brief tale ... that conveys a moral lesson, usually by giving human speech and manners to animals and inanimate things. Fables often conclude with a moral, ... an epigram ... related to folklore and proverbs" ( Baldick2008:123). A fairy tale is " a traditional folktale ... usually featuring marvelous events and characters, although fairies as such are less often found in them than princesses, talking animals, orges, and witches" (Baldick2008: 124). Speculative writing encircles several genres: horror, science fiction, literary substitute history, fantasy, uncanny fiction, supernatural fiction, utopia, dystopia, apocalyptic and post-apocalyptic work, and visual arts ( Atwood,2010). The thriller genre depends $n$ fast-paced elements of complication, astonishment and suspense; it makes the audience always expectant, worried, amazed and frightened.

A legend is "a story or narrative that which lies somewhere between myth and historical fact and which, as a rule, is about a particular figure or person" (Cuddon1998:484). It is a conventional tale that often tells about on a certain setting or a famous, often real, historical person. Like the myth, a legend completes spaces in historical reports, with abnormal stories. Unlike myths, legends seldom include stories about ancient deities, or abnormal happenings that cause world change. Mythic gods' tales may turn into a legend, and vice versa. On the other hand, a myth is

a traditional tale of deep cultural significance to a people in terms of etiology, eschatology, ritual practice, or models of appropriate and inappropriate behavior. The myth often (but not always) deals with gods, supernatural beings, or ancestral heroes... . mythos is: (1) Approaching the world through poetic narrative and traditional ritual rather than rational or logical thought. (2) The collected myths of a specific culture in a general sense rather than in reference to one particular narrative or character ( Literary Terms and Definitions, web.cn.edu/Kwheeler/) .

The commentaries and explanations attached within mythic stories represent the rubric mythography. Mythology is a body of anecdotes about the divinities, usually with overt theological qualities, that a certain cultural group may consider this untrue, on contrary to what their forefathers thought. . Being based on religious thoughts, mythology often explains real phenomena using rules of apocalyptic belief and causality, finds religious reasons behind customary practices and rituals dedicated to sanctified ceremonies, and makes predictions about the afterlife. Mythology includes genres such as: a legend ( about sound characters), a folktale or fairy tale ( about ghosts and devils), in addition to a myth. The components of folklore, such as tales, proverbs and customs, are transferred orally over the times. Rituals, songs, riddles, superstitions, legends and jokes are examples of folkloric elements that are found in literary works. Folkloric motifs are noticed in 
Shakespearean plays, fairy anecdotes, fables and archetypal tales. These are repeated images or plots in folktales or folklore. Folktales are spoken anecdotes every generation hears from the former one ( Literary Terms and Definitions, web.cn.edu/Kwheeler/). Archetypal literature contains " narrative designs, patterns of action, character types, themes, and images which recur in a wide variety of literature, as well as in myths, dreams, and even social rituals" ( Abrams:16). These archetypes have a deep effect on, and are instinctually embedded in, the reader's psyche. An etiological myth shows how persons or things were named, and tells about special or familial origins. An eschatological myth points to the end of the worldly being, and the afterlife fate of people. An apocalyptic work of art discusses the end of a specific era and the start of a new period. Post-apocalyptic works portray a post-catastrophe, often non-technological future, setting where the pre-disaster world becomes mythical. In alternate history literature, historical events are changed and made different from what really happened.

\section{Discussion}

Fantasy employed in modern Arabic Egyptian dramatic works finds its roots in earlier and ancient times ( Mlynxqualey,2013). There are some old attempts in writing marvelous or uncanny literature, such as Jahili verse, the Arabian Nights, and Ibn Tufayl's Hayy ibn Yaqzan. In the first half of the $20^{\text {th }}$ century, al-Manfaluti and al-Kawakibi wrote about an imaginary Mecca-held meeting attended by a number of world religion representatives to discuss the endangered world situation. Farah Antun's dramatic book is a dystopia about the conflict between three cities, Religion, Science and Money. Ahmad Ra'if's The Fifth Dimension presents a utopian anticipation about the end of the Cold War by creating a fanciful phase of this clash.

Several modern Egyptian writers have experimented in fantasy drama; most of them have been influenced by Western genres of the fantastic, the uncanny, or science fiction. Tawfiq al-Hakim's Ahl elKahf ( The People of the Cave, 1933), originated in a Quranic narrative, is a story of seven men from Ephesus, who sleep in a cave for over 300 years, and wake up in a completely different era. The play contains mythical cultural shock and rebirth into a new world, as well as legendary time travel. Al-Hakim's Shahrazad ( Scheherazade, 1934) retells the Arabian Night's legend. The writer cures the harsh king from his sense of despise of women, by the stories his wife Shahrazad tells every night. He decides to look for knowledge everywhere, and discovers that his wife, like the ancient goddess Isis, the source of life and illumination.

In the play titled Not a Thing out of Place,1966, al-Hakim offers an experiment in the postcolonial genre of magic realism that throws light on " the more collective, societal or mythic" values (Maufort:249), that are dictated by postcolonial culture. The play's characters are mentally affected by a magical power. The villagers decide to live in a fictitious world of 'positive disorder' that is different from the 1940's British colonizer's order ( Magnolia,2007). In the dialogue between two humble personae, for example, a donkey isassumed to be smarter than a philosopher as it has a larger head and brain ( al-Hakim1977:177). The characters often behave and talk strangely and abnormally and sometimes absurdly. This is the result of being in a " community where all values are equal all are meaningless" ( Badawi1987:85).

Al-Hakim's Awdat el-Shabab ( The Return of Consciousness) is a dystopian attack on the evil sides of scientific advance, that might be able to restore physical rather than spiritual youth. An Egyptian biologist, in collaboration with an American physician, tries to provide the human body with renewable molecules that prevent the advance in age, and retains youth. After several experiments on rabbits, the Egyptian doctor injects an old nobleman with the synthesis, who wakes up and finds himself at the age of twenty-five. This previously Pasha is not recognized by his wife and daughter who think he is a stranger who is in need of a favour. The family guess that the old Pasha has been kidnapped and killed, so they hold a funeral. The young man insists that the doctor should get him back to his old age and prestigious life, so the doctor suffers from mental breakdown, and his wife knows the truth of the wisely-speaking youth. The play closes when we discover that all this is a dream of the old Pasha who wakes up, and then is nominated for the position of the prime minister, but he dies and loses both the dream and the reality prospects.

In Bayt al-Naml (House of Ants), al-Hakim utilizes folktale ideas to examine a death wish. A young student of architecture is adored by a female fairy who tempts him to elope with her to the grand realm of genies. Being a coward, he dies of a heart attack. Al-Mukhrij ( The Film Director), composed of two parts, studies the relation between imbecility and mental soundness. First, an actor, who plays and indulgently reincarnates Othello, kills the actor playing Iago, in a frenzy of madness. Second, we listen to a dialogue between the niece of the insane actor and the movie director. She is a researcher in philosophy. Her strange ideas shakes the man's self-satisfaction. She abnormally likens the artistic creativity to divinity, and mentions the unusual expression 'the Supreme Director'.

Nahr al-Junun ( The River of Madness) also tackles the link between sanity and craziness (Badawi1987:49-60). It dramatizes an old legend, in which everybody in a kingdom has become mad because of drinking from madness-causing river water which has swarms of black serpents. The queen and the court doctor feel worried about the mind powers of both the king and his vizier who drink liquor instead of water and 
therefore show unbalanced behavior. Then the doctor and the queen irrationally decide that the king and the vizier should be healed by drinking the venomous river water; to keep their power they both agree to do so. Thus the reader becomes perplexed about whether the authority or the people is psychologically upright.

Rehla ela al-Ghad ( Voyage to Tomorrow) tells the story of a doctor and an engineer, who instead of being executed, they are to be punished by being sent in a national mission into space to do important scientific experiments. They travel to an unknown planet by rocket, and see some science fiction scenes: they need no food or water, no lungs to breathe, and even no heart; they become like machines that work with chargeable batteries. After some time they return to the earth, and find out that they have spent three centuries in space. They find themselves in the future world where almost everything is mechanized: e-journals, robots and vitamins. The engineer decides to join a domineering party that advocates a completely technological life, while the doctor is imprisoned with the party that calls for a return to a traditional life where human beings still have roles to play. This time travel play mixes both utopia and dystopia: the conflict between the rational and the sensuous or emotional (Saqr,2011).

Al-Hakim's Ya tale' el-shagarah( The Tree Climber) is about the absurd life of a humble husband and wife who live in the country. They both have unreasonable wishes that would not be achieved: the wife wants a baby, while the man hopes that he could harvest the fruit on the tree in his house garden. The man decides to kill a small lizard that lives in a hole under the tree thinking that it causes the fruit to fall down. But he is accused of killing his wife who goes away for a long time. A fortune teller predicts that the farmer would murder his wife, and uses her corpse as fertilizer for his fruit tree. The prophecy comes true, but the authorities do not punish him as his tree has four sorts of fruit and the dead body decays and disappears; instead they find a dead lizard.

In Al-Ta'am li-kul fam ( Food for Every Mouth), we learn about the story of a young scientist who works abroad on a project that could provide nutrition for all people in the world. When he returns back to his thirdworld country, some family trouble take him away from his studies that may be beneficial for all humanity. Learning about his project, one of the neighbours, a civil servant, decides to leave his earlier life of monotony and idleness, and write a book titled 'Voyage to Food'. The play tackles the conflict between private life and universal responsibility.

Masir Sorsar ( The Fate of a cockroach,1946) relates the story of a gentle husband who is suppressed by his domineering, coarse wife. She is always stern and bold. When the man finds a cockroach that cannot climb up to get out of the bath, he sees himself as this cockroach that is unable to escape suffering. He tries to help the insect, but his wife orders the maid to kill it. The husband expects that his destiny would be similar.

Lutfi Al-Khuli's al-Aranib (The Rabbits) is about a lawyer and his wife who do not mind taking a newly synthesized chemical substance, which has been created by a chemist - one of their family friends. The new medicine, which causes biological change in human sex, is experimented on the couple, so they exchange roles: the male converts to a female and vice versa. The husband and wife change their physical features or outer appearances, but their psyches remain the same. In Ibrahim Ramzy's Sarkhat Al-tefl ( I Hear a Baby Crying,1923), a non-pregnant wife always hears an imaginary crying of an infant. Her husband is always away on business, so her loneliness makes her enter into a world of vagaries and bad thoughts.

Yusuf Idris's Al-frafeer ( The Superman,1964) portrays the super character of Farfour who can turn himself into many different forms, and play many roles. He can be a folktale narrator who comments on events, a circus clown or juggler who does magical tricks, a puppet actor or a shadow puppet who inserts himself in the action of the play; we see him everywhere on the stage and in the middle of the spectators. The characters have illogical, sometimes absurd, conversations with Farfour, and he takes them into dreamy worlds of the uncanny. He often uses chemistry terms to create metaphors: he as well as other poor workers depend on their feudal masters just as an electron orbits a proton.

In al-Jins al-Thalith (The Third Sex), Idris uses some Biblical and Quranic allusions to the story of Cain and Abel. The play tells about a young chemist who, on hearing a fanciful calling voice, enters into a visionary world where he sees abnormal humans who do not communicate with him. Then in this supernatural realm he meets a scientist who tells him that he has visited the land inhabited by innocent, though primitive, the children of Abel who is considered dead on earth. The old scientist tells the chemist that the earthly people are Cain's children who are wicked, but have a higher rank in the evolution hierarchy. He asks the young man to marry a girl from Abel world so that a third kind of offspring may come to existence, and fill the earth with peace. But the play closes with a scene in which the chemist marries his assistant, revealing that love would beautify the world.

Idris's Jumhuriyyat Farahat ( Farahat's Republic,1954) is about a utopian world created by a policeman. This alternative reality contrasts with the harsh nature of his job as well as trouble occurring in a police in a police station, which frequently interrupts his daydream. He makes up a movie scenario: a poor, uptight man, 
who becomes rich by chance, decides to establish perfect republic where people enjoy prosperity, justice and compassion.

In Rashad Rushdy's Itfar-rag Ya salam ( Watch ... Wow ... Wonderful!, 1965), we see two anecdotes that go side by side: one in shadow puppetry, and the other in human acting. The play is based on old folktale ballads, the Arabian Nights as well as Sinbad's adventure tales. The shadow puppets tell the story of a merchant who suffers from a ruler's tyranny. On the other hand, the artist who controls the puppets is involved in another story. He is in love with a slave maid who was once possessed by a Greek sailor. The artist cannot enjoy his time with the woman as whenever he approaches her he fancies that she is accompanied by the sailor. The two stories often overlap, showing fantastic elements.

In Odeeb (Oedipus,1970), Ali Salim takes his inspiration from ancient Egyptian, rather than Greek, myth. He takes the audience into the marvelous world of dragons and gods. The antagonist is an ancient Egyptian Theban scientist who manages to rescue Thebes from a fierce monster. After forcing the beast away Oedipus sets out to do researches and projects that could protect the city from any coming danger. Being illiterate, the inhabitants of Thebes regard Oedipus as a hero who has killed the monster. In his laboratory, Oedipus could make modern inventions, that people have not known until the $20^{\text {th }}$ century. But the whole city is shocked when the monster appears again; the champion cannot beat the monster without the help of the people who are fettered by fear.

Ali Salim's Il-Nas illi fill-Sama'l-Tamina ( The People in the Eighth Heaven) takes its setting in a visionary planet where its inhabitants are tyrannically controlled by a cruel ruler and his assistants, a number of scientists. The king and his scholars decide to remove the gland of affection sense from the bodies of adults and children. They think that sentiment is a serious disease that should be eliminated. But the minister of medicine leads crowds of lovers, and they achieve a coup.

In Ali Ahmad Bakathir's Haroot wa Maroot ( Harut and Marut), the plot of the play is inspired by ancient Babylonian myth, Quranic verses and theories of anthropology. A herdsman's sister and his wife the queen compete in gaining the public loyalty by wearing charming clothes. The queen is also interested in travelling into space as she wants to be a ruler of the whole galaxy. She believes in a myth that tells about one of her forefathers who has tried to invade space but could not as the gods do not allow this. Then the play depicts the story of three angels who fall down to the earth, and appear as three courtiers. One decides to go back to heaven, while the two others fall in love with the queen. She learns from them how to travel into space, and then puts them in prison. When she reaches Venus, she is punished by turning into stone. Then heaven aids her husband to travel into space.

Bakathir's Dumu' Iblis ( Satan's Tears, 1957) tells how the senior demon, disguising in the form of a good-looking youth, appears to a pure, country virgin. He tries to tempt her to commit vice. But he falls in love with her. The woman begins to react to his vicious desire, but he fears that she would feel tormented after falling in sin. But his nature makes him seduce her, and then she gives birth to a child. She drowns herself in the river to take revenge on the devil. When the son grows up, he becomes a preacher at the spot where his mother died. The villagers listen to him, and this makes them blessed, self-satisfied, righteous and prosperous. Satan sends this virtuous man a fascinating girl to put him in her sin webs, but the young man succeeds in taking her to the realm of chastity. The demons ask Satan to get rid of his human son who would make the world a better place, and spoil their plans to do the reverse. Satan decides that one of the devils could induce a spiteful person to murder the youth. This happens and envy kills love.

In Mikhail Ruman's Al-Wafid ( The Newcomer), the playwrights portrays a mechanized modern city life. A young villager arrives into town and gets into an inn. When the hungry youth sits for food, the waiter asks him to fill in a form with his personal and professional information. But he is unable to find answers for all the questions addressed to him. The scene appears as an investigation in a police station. Everything in this hotel is done electronically, and everybody acts and speaks like a robot. The consider the newcomer a person from the past who lives with idle imagination. He does not manage to fill in the form and insert it into a machine to get a meal.

Salah Abdul-Sabour's Al-amirah Tantazer ( The Princess's Waiting) takes the audience into the mythic and supernatural stage of Shakespeare. A king punishes his daughter by putting her with three maids-in-waiting in a palace in an isolated spot in the woods. The princess who has been taken away from her lover, as well as her maids, expect that men may reach this place so that the women can enjoy the experience of love. Every night they pass their time by telling imaginary stories about a magic cock that turns into a prince by dawn. They imagine that a man wearing rags comes and kills the king with the princess's help; the play is full of many similar unnatural incidents, magic rituals and spells.

No'man Ashur's Lu'bat al-Zamen (Time Game) depicts world of fantastic that mixes both the past and the present. He makes historical or literary characters live in the present. In the beginning of the play, on a dark stage we hear the voices of Shahryar and Scheherazade who escapes death by travelling to the future with Shater Hassan. The cruel king looks for her in the present world; this opens his mind and heart to liberty and justice, so 
he becomes able to look forward to the future. In the present time, Scheherazade sees modern sights: casual hotel suites and lifts in high edifices.

In Farouk Khorsid's Habazlem Bazaza ( The Wines of Babylon), the characters swing between their past Arab tradition and the present or future dictated by Western culture. Modern lifestyle gradually replaces the conventional Arabian Nights glamour. Arabian Nights scenes are turned into Hollywood movies. This satire play presents figures who come from the past and dressed in old fashioned costumes, but who are attracted to the present situation led by their colonizers. The antagonist is a prototype of the corruption seen in this traditional setting; he just comments on the events though he is the main focus of the conversations between the other characters.

Nihad Sharif's Ahzan al-Sayyid Mukarrar ( Sorrows of Mr. Innocent,1990) tells the story of a young engineer who works in a factory that manufactures dolls. He also does a research that aims to prove that things or metals have feelings: they can love, hate, and can be happy or afraid. Then the owner of a robot factory asks this engineer to help his daughter who has broken her leg so that she may be able to move about. Therefore, they collaboratively manage to erect a robot to help the girl.

Alfred Faraj's Suqut Fir'awn (The Fall of a Phararoh,1955) takes inspiration from ancient Egyptian history. Akhenaton's responsibility as a king distracts him from spreading his new monotheistic religion. Thus he decides to leave the throne to his son, Tutankhamen, while the father sets out to preach the people about the worship of Aton, the sun god.

Faraj's Hallaq Bagdad ( The Barber of Baghdad,1963) is based on the Arabian Nights and Al-Jahiz's writings. Two different stories take place on stage. The persona of the barber appears in both. The play portrays various folkloric, archetypal figures: a just, tolerant, somewhat cheerful king, a greedy, domineering, cunning minister, a chance-utilizing courtier, a stingy trader, a pitiful adorer, a kind, an active, popular person, and a loquacious, interfering barber who provides sufferers with aid; but as a result he becomes jobless, and a tyrant governor punishes him. In the first tale, the barber helps a pretty, young lady to avoid being married to the aged minister, and marry her youthful lover. In the second story, the barbers helps a young widow to restore her husband's wealth which has been usurped.

Faraj's Ali Janah of Tibriz is a fantasy farce that takes roots from the Arabian Nights, Ibn Daniyal's shadow puppetry, and the puppet art known as karagoz. A young merchant takes a trade caravan belonging to the court, and decides to give the goods to the needy people for free. When the courtiers arrange to execute him, the other merchants and the people manage to save him, and then he marries the princess. The play " raises many questions: to what extent can dreams be considered either lies or truths? Can a radical who bases his beliefs on a myth succeed in creating change? (qtd in Bdawi 1987:181). The character of the merchant's assistant with his clown costume represents the imaginary world of puppet theatre.

\section{Conclusion}

Writers of modern theatre drama in Egypt have been trying to attract spectators to the art presented on stage. The readers and audience are often infatuated with verse works or songs or novels. To take the people into the theatre, the playwrights often create stories that belong to the fantastic genre. They make up alternative worlds in order that readers quit the suffocating reality and find relief in imaginative realms. The fantasy plays discussed here contain several non-realistic elements: science fiction that opens the people's minds to future utopias or dystopias, time travel that take the readers to the past where they ponder over their present situation, the supernatural in which the spectators willingly indulge themselves. Modern Arabic drama in Egypt has the interesting characteristic of being technically non-traditional; it belongs to the art of the avant-garde or the experimental. Egyptian Dramatists, who emerged in the second half of the twentieth century and afterwards, have often had a sense of being divorced from their surroundings; as a result the have resorted to escapist literature in order that they could freely represent the environment that has excluded their art.

\section{References}

[1]. Abdel-Aziz, Saad. Al-ostura wal drama ( Myth and Drama). Cairo: Anglo-Egyptian Bookshop,1966

[2]. Abo-Haif, Abdalla. Al-masrah al-Araby al-mo'aser: qadaya wa ro'a wa tajareb (Contemporary Arabic Drama: Themes, Visions and Experiments). Damascus: AWU,2002

[3]. Abrams, M.H. A Glossary of Literary Terms. $7^{\text {th }}$ ed. N.Y: Cornell University,2003

[4]. Al-Hakim, Tawfiq. Fate of a Cockroach and Other Plays. Trans. Fuad Megally. Bashiru: U of Wisconsin. Vol 4. No 2, 1973

[5]. Andrew, Elizabeth Mac. The Gothic Tradition in Fiction. New York: Columbia UP,1979

[6]. Atwood, Margaret. "The Handmaid's Tale Study Guide: About Speculative Fiction”. Archieved. April 8.2010. retrieved. April 16.2010

[7]. Badawi, M.M. Modern Arabic Drama in Egypt. Cambridge: CUP,1987

[8]. Bahie, Essam. Al-khayal Al-elmi fi masrah tawfek al-hakem( Science Fiction in Tawfiq al-Hakim's Drama). Cairo: GEBO,1999

[9]. Baldick, Chris. The Oxford Dictionary of Literary Terms. $3^{\text {rd }}$ ed. New York: OUP, 2008 Clute, John, and Peter Nicholls. The Encyclopedia of Science Fiction. New York: St. Martin's, 1993.

[10]. Cuddon, J.A. A Dictionary of Literary terms and Literary Theory. $4^{\text {th }}$ ed. Oxford: B.Blackwell,1998 
[11]. Freud, Sigmund. "The Uncanny". The Standard Edition of the Complete Psychological Works of Sigmund Freud, ed. \& trs. James Strachey, vol. XVI (London: Hogarth, 1953), pp. 219-252

[12]. - ----- . The Uncanny. Trans. D. McLintock. London: Penguin Books,2003

[13]. Gunn, James, ed. The Road to Science Fiction . N.Y: Scarecrow Press, 2002

[14]. Jayyusi, S.K. \& R. Allen, eds. Modern Arabic Drama. N.Y: Indian Series, 1995

[15]. Magnolia, Tiffany. Within the Kingdom of this World: Magic Realism as Genre. Michigan: UMI Press,2007

[16]. Mandour, Mohamed. Masrah Tawfeek El-hakem ( Tawfiq al-Hakim’s Drama). Cairo: Nahdat Misr Publishing, 1960

[17]. McNelly, Willes E. "Bradbury, 1920-." In Science Fiction Writers: Critical Studies of the Major Authors From the Early Nineteenth Century to the Present Day, edited by Everett Franklin Bleiler, 171-78. New York: Scribner's 1982.

[18]. McNurlin, Kathleen Woitel. "Question of Ethics: Themes in the Science Fiction Genre." Interdisciplinary Humanities 12, no. 4 (1995): 19-36.

[19]. Mohsen, Hassan. Al-mo'athirat al-gharbya fi al-masrah al-masry al-mo'aser ( Western Impact on Contemporary Egyptian Drama). Cairo: El-nahda El-arabya,1979

[20]. Nur-eddin, Khalil. “ tafsir jadid li masrahyat ya tale' el-hagara” ( A New Interpretation of The Tree

[21]. Climber). Al-Hilal. (March,1964)

[22]. Osman, Ahmed. Al-masader al-klasikia li masrah tawfeek al-hakeem ( Classical Sources of Tawfiq

[23]. Al-Hakim's Drama). Cairo: GEBO,1978

[24]. Patrouch, Joe." Symbolic Settings in Science Fiction : H.G. Wells, Ray Bradbury, and Harlan Ellison." Journal of the Fantastic in the Arts I, no. 3(1988): 37-45

[25]. Pell, Sarah-Warner J. " Style Is the Man: Imagery in Bradbury's Fiction." In Ray Bradbury. edited by Martin Harry Greenberg and Joseph D. Olander, 186-94. New York: Taplinger, 1980.

[26]. Saqr, Ahmed. "qiraa tahlilya fi masrah al-khayal al-elmi” ( An Analytical Reading in Science Fiction

[27]. Drama). Al-Hewar Al-Motamaden. Issue 3359.(5-8-2011)

[28]. Stockwell, Peter. "Language Knowledge, and the Stylistics of Science Fiction. "In Subjectivity and Literature from the Romantics to the Present Day, edited by Pilip Shaw and Peter Stockwell, 101-12, London: Pinter, 1991.

[29]. Todorov, Tsvetan. The Fantastic. Ithaca: Cornell UP, 1975

[30]. Zamora, Lois P. \& Wendy B. Faris \&, eds. Introduction to Magical Realism: Theory, History, Community. U.S: Duke UP,1995 